\title{
Renovabio: Innovation and Sustainability at the New Brazilian Biofuels Policy or The Emperor's New Clothes?
}

\author{
Arnoldo S. Lima and Toni Fabiano
}

\section{ABSTRACT}

Biofuel policies are an ongoing matter for both developed and developing countries. Brazil, a giant world producer, has a historical roll of regulations and laws that affect the sector. Nevertheless, studies from a political ecology perspective, which pay attention to the impacts of power relations and discourses in political outcomes are scarce. In this sense, we focus on the National Biofuel Policy (Renovabio), launched in 2017, to analyze discursive coalitions as well as perceptions from social actors settle in a biofuel production territory. We sought to understand contradictions between discourses and practices within Renovabio and how they reproduce traditional Brazilian Biofuel policies. To answer these questions, we used Atlas.ti software to support a content and critical discursive analysis in order to detect distinct perspectives, narratives and interests during Renovabio's implementation. We draw on: i) statements from stakeholders, lobbyists, and Congress members; ii) Bills, Law Projects and ordinances texts from the special commissions and committees; iii) speeches from plenary sessions occurred on the National Congress; iv) Public Audiences contributions; v) articles from biofuel magazines and specialized websites; and, vi) digital platforms from lobbies and interest groups; We also conducted 24 interviews with community members, farmers, local government officials, civil associations, and industry representatives in the state of Goiás, a large ethanol/ sugar-energy production territory. Results pointed to a strong ecological modernization discourse deployed to justify the rapid policy implementation and to legitimize economic incentives, particularly ecological labeling/certification. Renovabio's goals, speeches and practices are in many senses contradictory and reproduce problems detected in previous biofuel policies that dim legislative transparency, weakens accountability and tramples society participation and representativeness over biofuel development.

Keywords: Biofuels, Governance, Ethanol, Biodiesel, Regulations, Certifications, Discourse, Participation and Sustainability.

Published Online: October 13, 2020

ISSN: $2684-446 \mathrm{X}$

DOI :10.24018/ejgeo.2020.1.5.74

Arnoldo S. Lima*

Universidade de Brasília/ Centro de Desenvolvimento Sustentável (UnB/CDS), Brasília, Brasil. (e-mail: arnoldosan@gmail.com)

\section{Toni Fabiano}

Universidade de Brasília/ Centro de Desenvolvimento Sustentável (UnB/CDS), Brasília, Brasil.

(e-mail: fabtoni@gmail.com)

*Corresponding Author

\section{INTRODUCTION}

As biofuel enters maturity worldwide, they are followed by environmental and social problems[1]. Large-scale production from sugarcane and soybeans renders biofuels responsible for significant changes in land use, destruction of biodiversity, degradation of soils, and water contamination [2]. The expansion of biofuels market is also associated with competition between food and fuel production, the worsening of labour conditions and negative impacts on livelihoods in the raw material fields [3].
In Latin America, energy policies emerged both to stimulate biofuel production and to avoid or to mitigate its negative impacts [4]. In Brazil a set of recent regulations gained prominence promoting voluntary certifications, economic incentives, and sustainability standards in the industry. However, little attention has been paid to the outcomes of such policies [5], [6]. There is scarce evidence these mechanisms assure eco-social efficiency in the biofuel chain [7], which reinforces further debates about environmental risks and social challenges [8].

Considering this background problem, this paper explores biofuels beyond technical and economic approaches. We explore the nature of policy formation and observe those 
energy sources through political ecology lenses, in which we focus on power relations and the construction of discursive coalitions. We explore how those relations potentially affect policy goals, the choice of policy instruments, and governance performance. Also, we discuss to what extent they produce trade-offs between environmental and social outcomes [9]. Those elements are scarcely debated in the discussions on the sustainable development of (bio)energy [10]. Accordingly, there has been little discussion on the ways sustainability is accessed and used in the context of biofuel regulations [11].

In this sense, we focus on the Brazilian National Biofuel Policy (Renovabio), launched in 2017, to answer whether this new regulation - linked to 2016 Paris Agreement commitments - represents an innovation and a sustainability benchmark in biofuel regulation or reproduce patterns detected in previous policies. As a guiding hypothesis we assume quite generally that the new policy reproduced traditional forms of regulation biased by power asymmetries. The innovation is kept at a rhetorical level thought the deployment of an ecological modernization discourse that legitimize certification and economic incentives, which in turn jeopardize participation, equality, transparency, and accountability.

\section{ENVIRONMENTAL DISCOURSES \& POLICY FORMATION}

The discursive analyses are focused to understand how distinctive social constructions of nature may be deployed in policy formation [12]. This approach starts from the perspective that environmental policies are embedded in different meanings of nature, environment, and environmentalism [13], rather we argue that they are closely related to disputes and even power stunts amongst interests groups within political arenas [14]. In this sense, the discursive analyses is a tool to comprehend how normative constructions were established and to understand how they unfold at the ground [15].

In the case of energy policies, similar analyses may be used to identify how discursive patterns consolidate, clash, or overlap; and are reproduced in specific policy debates and agreements within the political and institutional arrangements. In this sense, these trends usually occupy political arenas as Luke [16] points out. We borrow the idea of an environmental Panoptic (Fig. 1) wherein distinctive groups battle to define concepts like environment and sustainability, and by doing so they assert their particular views, values and interests over the logic of policy formation.

The Environmental skepticism mainstream, for example, argues that impacts caused by human activities, such as fossil fuels, use are not clear, or less harmful than reported by scientists. Also called Denialists; they are conservative think tanks and politicians representing the "polluter industrial complex" [17], that dismiss the anthropogenic cause of global climate change [18]. They support networks of public relations firms, campaigns, nonprofit groups, political action committees, and lobbying actions presenting extractive and chemical industries in a positive perspective and "deny any claims of systematic environmental wrongdoings" [19].

Within the Utilitarian current, the environment is the locus of natural systems, in which organisms and biogeochemical elements are the necessary core for the production of food, drugs, fibers, minerals, energy, biomass and genetic materials [20]. Utilitarian's approach supports the anthropocentric view of uncurbed nature use and is reluctant to incorporate natural rights or intrinsic values of ecosystems, biomes, and natural organisms [21].

For the Eco-Populism trend, the environment is a necessary subject in the political debate, and environmentalism is a form of social action and social engagement. The claims are connected to environmental justice, as in the defense of local and indigenous people against the exploitation of their resources by outsiders [22]. The 'timely environmentalism', discourse refers to the appropriate constructions of environmental commitments and a parsimonious use of the nature. It is also connected to the 'new corporate environmentalism' within which companies promote the 'greening of business' to highlight concerns and reverences for nature conservancy [23].

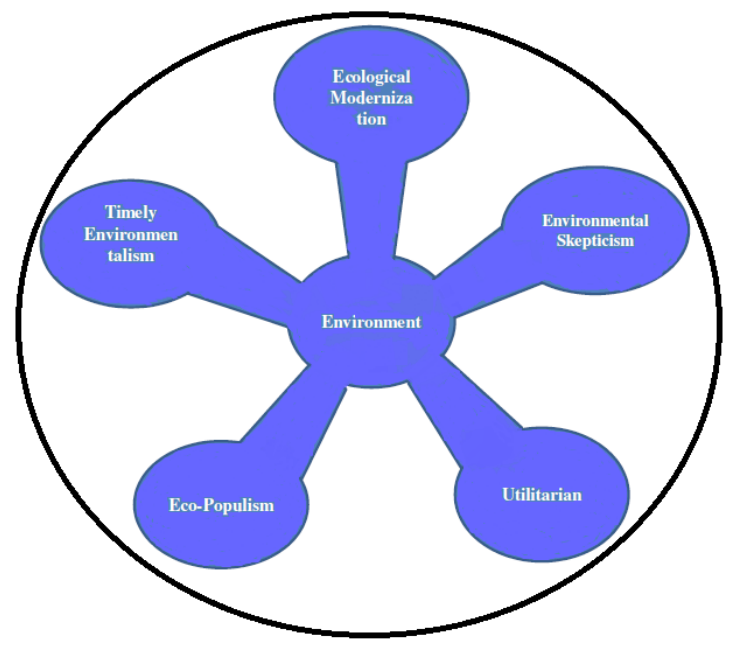

Fig. 1. The Environmental Panoptic.

The ecological modernization discourse in turn is built upon a technicist understanding of the environment, and a technocratic view of environmentalism. The environment is understood as an entity that can be controlled by science advancements. Common ecological modernization tools are standardization, certifications, and economic incentives. Issues such as pollution, climate change, acidification of the oceans, among others, are treated as imbalances that can be remedied through instrumental and economical rationality. In this perspective, little attention is paid to the social and ethical aspects of interventions and manipulation of the environment [24].

\section{INTEREST GROUPS AND COALITIONS AT BRAZILIAN BIOFUELS}

Powerful interest groups linked to ethanol and biodiesel influence the political process inside the Brazilian National Congress and within the executive branch. Those groups 
include organizations as the Sugar Cane Industry Union (UNICA); the National Industry Center for Sugar-energy and Biofuels Sector (Ceise); and Bioenergy Union Producers $(U D O P)$; Biodiesel Producers Association (Aprobio) and the Biodiesel League (Ubrabio).

UNICA exerts domestic influence inside the National Congress through lobby over decision-makers. It also has representation offices in the US and in Europe to defend the interest of sugarcane and ethanol producers. [25]. Organizations such as UNICA, the National Sugarcane Forum, and the North-eastern Union of Sugarcane Producers became notorious for opposing the Sugarcane Agroecological Zoning, which in 2009 restricted the expansion of sugarcane and ethanol plants for the Amazon and Pantanal biomes.

Those organizations define themselves as: 'interlocutors with society and the government to mobilize efforts, resources and knowledge in the pursuit of development' (RNB/Atlas.D01). They keep websites and sponsor reports, specialized magazines, public campaigns and studies and publications targeted at line ministries and other public agencies. Together they form a solid interest group that exerts a significant influence on agricultural policy, energy, and industrial development particularly by supporting members of the rural caucus (Parliamentary Front of Agriculture -FPA) in the in the National Congress.

The Biodiesel Parliamentary Front (FrenteBio) between 2014 and 2018 gathered 202 of the 513 representatives and 03 Senators engaged in defending biodiesel. FrenteBio is known to support the increase of the mandatory blends of biodiesel to mineral diesel in Brazilian fuel supply. The caucus size usually oscillates in numbers every four years when parliamentary elections are held. FrenteBio 2019 shows strength to keep the number of representatives even after a large change on the National Congress representatives. FrenteBio is also connected to the FPA, a powerful parliamentary group engaged in supporting agribusiness, livestock, rural development and agroindustrial activities.

TABLE I: MAIN INTEREST GROUPS ON BIOFUELS POLICY FORMATION

\begin{tabular}{c|c|c|c}
\hline \multicolumn{3}{c}{ Parliamentarian Fronts involved on biofuels policy formation } \\
\hline $\begin{array}{c}\text { Political or } \\
\text { interest } \\
\text { groups }\end{array}$ & $\begin{array}{c}\text { Parliamentary } \\
\text { Front of } \\
\text { Agriculture } \\
\text { (Bancada } \\
\text { Ruralista) }\end{array}$ & $\begin{array}{c}\text { Biodiesel } \\
\text { Parliamentary } \\
\text { Front } \\
\text { (FrenteBio) }\end{array}$ & $\begin{array}{c}\text { Environmental } \\
\text { Parliamentary } \\
\text { Front } \\
\text { (Bancada } \\
\text { Ambientalista) }\end{array}$ \\
\hline \multirow{3}{*}{ Members } & 2014 - 2018 & 2014 - 2018 & 2014 - 2018 \\
& 226 Deputies & 234 Deputies & 228 Deputies \\
& (Lower House) & (Lower House) & $\begin{array}{c}\text { (Lower House) } \\
\text { 16 Senators }\end{array}$ \\
\hline Period & After 2019 & After 2019 & After 2019 \\
\hline \multirow{3}{*}{ Members } & 235Deputies & 203 Deputies & 216 Deputies \\
& (Lower House) & (Lower House) & (Lower House) \\
& 38 Senators & 03 Senators & 06 Senators \\
\hline
\end{tabular}

The FPA (Bancada Ruralista) is one of the largest and most organized political groups within National Congress. Between 2014-2018 periods FPA had 226 representatives in the Chamber of Deputies and 27 Senators representing interest of entities as the Brazilian Rural Society (SRB) and the National Confederation of Agriculture (CNA). Ruralistas usually act and vote against the Environmental Parliamentary Front (Bancada Ambientalista) in the Plenary Session and in occasions on the Sustainable Development \&
Environment Commission (CMA) defending different positions on agricultural products regulation, MGO's and agrochemicals legislation, land demarcation, and especially the Brazilian Forest Code.

The environmental caucus (Bancada Ambientalista) is not so Strong and usually opposes the Agricultural caucus. Nevertheless, in the case of biofuels, they agree in many points, for members of the latter group, in general, consider biofuels less damaging than fossil fuels.

\section{BRAZILIAN BIOFUELS POLICIES: BETWEEN DISCOURSES \& PRACTICES}

\section{A. The National Ethanol Program (Proálcool)}

In the early 1970s, Brazil was experiencing the "economic miracle" when (GDP) grew up to $12 \%$ per year. Such an impressive growth pushed the demand for fuels, mostly imported at that point $-75 \%$ of Brazil's oil supply came from abroad (about 753,000 barrels per day) when the first oil shock occurred in 1973. The first measure to cope with the crisis was indebtedness, for international credit was abundant and interest rates low. The second measure was the substitution of imports by means of prospecting new oil deposits, and the development of alternative fuels and sources of energy [27].

In this context, the National Ethanol Program (Proálcool) was created in 1975 to explore the high sugarcane outputs, thus far used in the sugar industry, to produce ethanol in large scale and to assure national security. Policy goals were also connected to job generation, revenues and economic growth as well to the promotion of new technologies and incentives to agroindustrial activities. The Proálcool guidelines promoted a large expansion in agribusinesses activities and replaced significant part of the gasoline consumption in light vehicles. Brazil developed a competitive sector that made this biofuel policy a case of successful institutional and technological change aimed at developing a renewable energy source [28].

The policy however was designed through a strong topdown model of state intervention, under the military government, based on a centralized bureaucracy and a nationalist /developmentalist rationality to justify public subsidies along the supply chain [29]. The government offered credit guarantees and low-interest loans to new distilleries and began to purchase ethanol at encouraging prices. 'Let's unite, make alcohol' was a propeller motto strategy applied for the giant state-owned oil company, Petrobras, in charge of biofuel acquisition and distribution throughout the country [30].

In this context, environmental concerns were absent from the policy making and nature was seen through a Utilitarian point of view or merely as a physical space able to offer goods and natural resources to provide economic growth and the expansion of bioenergy sources. That rationale Nationalism; Developmentalism and Utilitarism - together promoted the spreading of large-scale sugarcane plantations, with severe negative socio-environmental outcomes [31].

More than thirty years after Proálcool, Brazil still experiences an expansion of sugarcane driven by the 
domestic market and policies to support biofuels. The territorial dynamics of sugarcane moved part of the plantations and plants from historical croplands - Northeast and São Paulo state - to large areas of native savannah (Cerrado) in the Center-West Region [32]. In 2000, those areas had $7.6 \%$ of the sugar cane plantations in Brazil (in area). In 2014 that amount reached 17.2\%. The total sugarcane area in the Cerrado increased by a factor of 4.84 times, whereas the growth for the whole country grew by a factor of 2.14 [33].

\section{B. The Biodiesel National Program (PNPB)}

The viability of biodiesel in Brazil consolidated when the country became one of the largest soybean producers and vegetable oil processors in the world, by the early 1990s. It was also reinforced by a historical context, with the debates related to greenhouse gases emissions, climate change, and the opportunities for biofuels development. The national biodiesel policy $(P N P B)$ was launched in 2004 to create an innovative biofuel market trying this time to avoid geographical concentration, single crop focus, dominance of agribusiness, and exclusion of smallholders farmers, as it was the case in the Proálcool [34].

The Oil, Natural Gas, and Biofuels National Agency $(A N P)$ and Petrobras launched the 'Biodiesel: The Planted Energy' campaign as a form to promote local development, recover degraded areas, develop food and energy agricultural systems, and diversify oilseeds in different biomes and regions [35]. Policy-makers aimed at building a multi-level participatory governance system, in order to avoid a 'bio-oil curse', which could lead to the capture of the policy by a few powerful stakeholders, and the reproduction of the negative social and environmental impacts of Proalcool [36].

In a context of left-wing government (President Lula, 2003-2010) $P N P B$ elaboration had a strong Eco-Populism discourse aimed at going beyond technological and financial efficiency to include social and environmental benefits. Several stakeholders and institutions were involved, such as: Large oilseed \& soy processing groups, biodiesel producers associations; grain traders; labour unions; farmer's leagues; rural cooperatives, and national and subnational government agencies. A certification mechanism was created - the Social Fuel Seal - to supply subsidies and economic incentives to industries and cooperatives interested in establishing partnerships among each other and with smallholders.

After ten years of subsidies and economic incentives, $P N P B$ did not created cooperation, but rather, fierce competition in the soybean grains and derivates trade, especially soy bran. Raw material production remained geographically concentrated and based in a single large crop monoculture. Political arenas remained concentrated at the federal scale resulting in an unequal distribution of benefits and rights. Mechanism of community participation and representativeness did not emerged to counter-balance power asymmetries [37].

A timely socio-environmental discourse became the main standard used for the large energy companies and soybean processors to legitimize certifications and keep production. The policy did not break away from traditional top-down structures as the political arrangements and production fell under control of elite stakeholders. The regulation neither decentralized authority nor delegated further regulatory autonomy to states or local governments.

\section{National Biofuel Policy (Renovabio)}

Throughout the decades of 2000 and especially after Rio +20 the Brazilian government was engaged in debates within the United Nations Framework Convention for Climate Change (UNFCCC). During the $21^{\text {st }}$ Conference of the Parties (COP-21), the representatives of Brazil ratified the Paris Agreement along with 195 signatory countries. The National Biofuel Policy (Renovabio) was conceived in 2016, amidst a severe domestic political turmoil, to respond to Brazil's commitments and deliver its intended National Determined Contribution (iNDC).

The Bill Project 9,086 was presented by the Biodiesel Parliamentary Front leader and current UNICA president, deputy Evandro Gussi, swiftly on November 14, 2017. It was approved after the first plenary session, on November 28 at the Lower House, and at the final deliberation, on December 20, 2017, in the Senate. The policy entailed a series of legal measures designed to promote energy efficiency; curbing deforestation and decreasing greenhouse gas emissions for both the ethanol and biodiesel chains.

Under RenovaBio structure (Fig. 2), biofuels producers and importers would be able to calculate their 'Energy and Environmental Efficiency' using a Life Cycle Assessment tool (RenovaCalc) in order to receive accreditations for 'Efficient Production of Biofuels'. Inspection firms would audit calculations and issue the Decarbonization Certifications (CBio's) rights, supervising raw materials eligibility and biofuel production free from deforestation areas.

Under this structure, biofuels producers may negotiate their CBio's both in an open stock market and especially in a mandatory stock market established by the ANP. Renovabio structure would therefore stimulate agribusiness activities and make biofuels central in the country strategy to accomplish national goals to reduce $43 \%$ of Brazil GHG emissions until 2030 (based on 2005 levels).

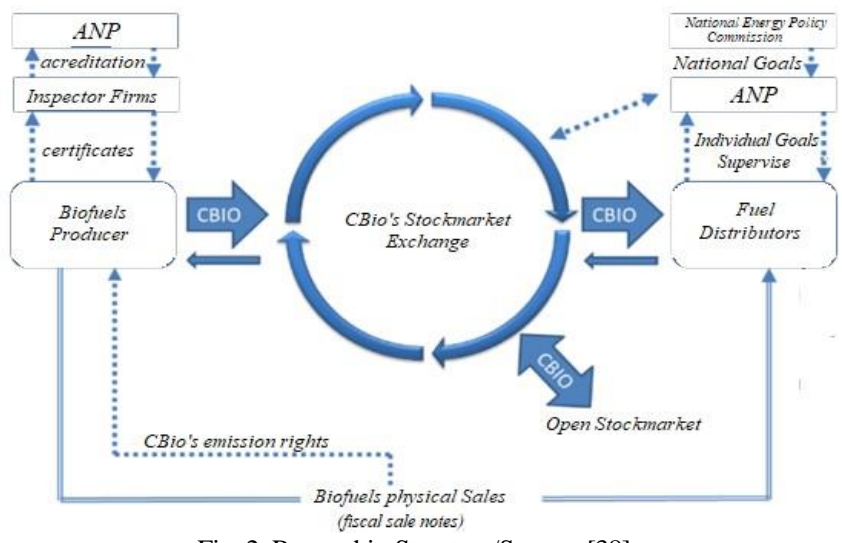

Fig. 2. Renovabio Structure/Source: [38]. 


\section{Method AND Materials}

The present study is based on documentary, bibliographical, and field research. We sought to identify discursive coalitions behind the 2017 National Biofuel Policy and critically analyze narratives of different stakeholders to detect how these perspectives may reveal social and environmental contradictions. We first performed a content and critical discursive analysis using Atlas.ti software to support qualitative data management from: i) statements of stakeholders, lobbyists, and Congress members; ii) Bill Project texts and correlative ordinances notes; iii) Meeting minutes of Special commissions and committees; iv) parliamentarian speeches and votes registered on the Chamber of Deputies and Senate Diaries; vi) contributions on Public Audiences; vii) biofuel magazines and specialized websites; viii) interest groups digital platforms campaigns. We then conducted 24 semistructured interviews in a large bioenergy production territory in the Ceres Microregion, state of Goiás. Informants included community leaders, small landholders, local government, civil associations, and industry representatives. In a third stage, we identified most common conceptual patterns and repertoire of discourses deployed during the legislative process and in the interviews with the social actors that we heard in the field study. And fourth, we use the main discourses from selected quotations - referenced as (RNB/Atlas.00) - to expose common assumptions and narratives. In possession of those narratives we analyse Renovabio using four governance drivers: i) Decentralization; ii) Participation; iii) Transparency \& Accountability, and; iv) Equity. We rated the results in a Likert scale transforming qualitative data to quantitative measures ranging from - 2 (worst scenario) to +2 (better scenario).

\section{Results}

At least 65 central codes were identified from analyzes of statements, speeches, testimonials, and narratives that were studied with the support of Atlas.ti. These codes expressing overriding concepts and its frequency can be observed intuitively as a general conceptual framework represented by the software word cloud (Figure 03). It is worth to note that the aim here is identify the most incident concepts to subsequently analyze critically those assumptions, ideas, logical constructions, and possible contradictions.

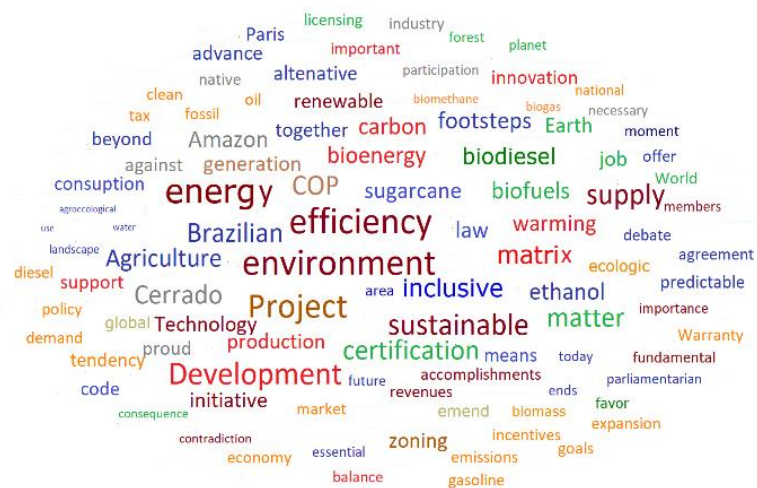

Fig. 3. Renovabio's conceptual cloud / Source: from authors applying Atlas.ti word cloud.
We expected to find a broad frequency of 'biofuels' concept on debates aimed specifically to define regulatory means and goals on these energy sources. However, the conjunctions of ideas surround it gained particular meanings or assumptions accordingly to particular stakeholders, interest groups and their perspectives and speeches. On the Renovabio's perspectives and narratives it systematically emerged linked to a set of arguments that exalted particular rationalities to define and support "bioenergy as a world tendency" (RNB/Atlas.D02); or as an indubitable form to reduce emissions, respond to market demands, and especially "guarantee to the ecologic need" (RNB/Atlas.D03) through a clean energy policy.

Similar constructions were also deployed from other core concepts and applied to constructed rationalities on the 'biomass' and 'sustainability' understandings showing Renovabio as "an essential national project" (RNB/Atlas.D04) able to support the expansion of renewable sources and to boost the Brazilian agriculture, industrial activities, and the regional economy in the biofuel poles. In this case, biofuels, bioenergy, biomass, and sustainability form a repertoire of codes to highlight biodiesel and ethanol protagonism, but also biogas and biomethane as a way "to surf at the forefront of an irreversible world movement, driven by the low carbon economy" (RNB/Atlas.D05).

Similar constructions commonly presented RenovaBio as "a cutting-edge policy for biofuels and for the sustainable Brazilian development" (RNB/Atlas.D06). 'Sustainable' is a recurrent concept (27 occurrences) linked to supporting narratives coming from congressmen, lobbysts, and government representatives (Table II - left column). Sustainability indeed is a guiding narrative surrounded by an iterant repertoire of codes attached to particular vindicatory rationalities on: i) energy efficiency; ii) environment efficiency; iii) innovation; iv) technology; and iv) energy matrix. These perspectives were systematically employed by representatives of the FPA (Bancada Ruralista), FrenteBio and, surprisingly, by members of the Environmental Parliamentary Front (Bancada Ambientalista) revealing no significant contradictions concernung the meaning of sustainability during the policy formation.

The 'energy efficiency' rationality starts from a series of narratives and texts that exalted biofuel sector commitments to apply international norms as ISO 14040 and ISO 14044, "producing more and better energy" (RNB/Atlas.D07), showing competence to implement new methodologies as RenovaCalc's and to be compliance to reduce biofuels carbon footprint impacts through a life cycle assessment parameters. This feature emerged from claims to demonstrate Brazilian government involvement to reach the iNDC's established under the Paris Agreement. It also was deployed to exalt the industry commitment to produce bioenergy following "environmental responsibility by promoting the reduction of pollutants" (RNB/Atlas.D08). 
TABLE II: REPERTOIRE OF CODES \& MAIN VINDICATORY RATIONALITIES Repertoire of codes \& main rationalities

\begin{tabular}{ll|l}
\hline & $\begin{array}{c}\text { Coalition \& Interest Groups, } \\
\text { Congressman, Lobbyist, Official } \\
\text { Stakeholders \& Government } \\
\text { representatives }\end{array}$ & $\begin{array}{l}\text { Local government, communities' } \\
\text { leaders, rural associations \& } \\
\text { cooperatives, sugarcane-energy } \\
\text { representatives, industry } \\
\text { managers, workforce, farmers }\end{array}$ \\
\hline i) $\quad$ Energy efficiency (sustainability); & $\begin{array}{l}\text { i) Economic growth } \\
\text { (prosperity) }\end{array}$ \\
\hline ii) $\quad \begin{array}{l}\text { Environment } \\
\text { (sustainability); }\end{array}$ & ii) Job generation (prosperity) \\
\hline iii) & Technology (sustainability); & $\begin{array}{l}\text { iii) Revenues and taxes } \\
\text { (prosperity) }\end{array}$ \\
\hline iv) & Innovation (sustainability); & $\begin{array}{l}\text { iv) Landscape (environmental } \\
\text { outcomes ) }\end{array}$ \\
\hline v) Energy matrix (sustainability) & $\begin{array}{l}\text { v) Land tenure (social } \\
\text { outcomes) }\end{array}$ \\
\hline vi) Development (prosperity); & $\begin{array}{l}\text { vi) Water \& Air quality } \\
\text { (environmental outcomes) }\end{array}$ \\
\hline
\end{tabular}

'Efficiency' (47 occurrences) connected to 'environment' (49 occurrences); and 'energy' (50 occurrences); formed another set of codes linked to rationalities of 'environment efficiency'; 'environment performance', and 'environment responsibility'. These were the most common narratives applied by powerful interest groups and lobbies, as well as in the majority of speeches that boosted Renovabio's approval in the National Congress. That set of statements for instance supported the defences "on a law that advocates sustainability through a long, strong and vigorous path towards a green economy" (RNB/Atlas.D09).

The 'technology' concept (17 occurrences) is also a cornerstone element, commonly applied in campaigns promoted by the biofuel companies, as well as in the statements made by FrenteBio congressmen. The term was used as a central element to illustrate commitment to science and the willing to respond to the challenge to improve and modernize the national energy matrix. Calls for the bill approval commonly claimed efforts to "turn the page and invest in science, technology and innovation" (RNB/Atlas.D10) and stimulate "clean fuels that make Brazil sustainable and committed to the Climate Agreement" (RNB/Atlas.D11).

A similar rationality is forwarded in the use of 'innovation' (15 occurrences) as a key element of logical construction in statements, ordinances texts, and campaigns. This rationality comes from the clamour that "RenovaBio is a Brazilian innovation and will serve as a world reference in biofuels" (RNB/Atlas.D12). What is implied is that, besides the new procedures, methodologies, and techniques, the set of innovative policy guidelines would became a mark on domestic energy regulation and production and an example to be followed globally.

Also highly consensual were narratives surrounding 'development' (32 occurrences), which implied prosperity and economic growth. Those claims projected Renovabio as a " a law sensitive to national development and to a sector that generates jobs, income, work, wealth and prosperity for our nation" (RNB/Atlas.D13), or as an essential project able to gather "the support of different parties that we never imagined [vote] together to help create jobs, help economy, and help the country to achieve a better development" (RNB/Atlas.D14).
The 'prosperity' rationality also emerges from narratives of some social actors on Ceres energy landscape, especially within local government authorities, sugarcane-energy representatives, and workforce (Table II - right column). These broad narratives were ignited by our questions related to biofuels, (bio) energy, sugarcane, land, and development. The answers initially came connected to perspectives highlighting positives outcomes concerning 'economic growth'; 'job generation; 'revenues, and taxes' generation. "The citizens here like the plants because of jobs and occupation" (RNB/Atlas.D15) as highlighted by a workforce member referring to the broad acceptation that bioenergy industries have amongst the community. The logic that "they employ a lot of people, and are entrepreneurs committed to our economy" (RNB/Atlas.D16) or "their revenues save the municipality from this widespread crisis" (RNB/Atlas.D17) is a common narrative especially applied to local government speeches to legitimize biofuel production chain.

The logical constructions and assertions surrounding the economic benefits, job generation and revenues are also identified among some community members, but they also reveal concerns about socio and environmental outcomes. "Fertilization with vinasse makes the air horrible, but we don't like to complain too much because [company owner name and former mayor] is too good to us and helps the economy here" (RNB/Atlas.D18). This kind of statement reveals a sensitive economy, dependent on the biofuel sector, in the Microregion of Ceres.

The roll of questions during interviews also brought narratives linking biofuels to the landscape changes due to the sugarcane expansion. "In the beginning sugarcane fields were very small, but now it's everywhere" (RNB/Atlas.D19) or the "bushes and the native fruits that we used to had around here ... all gone ... everything turned to sugarcane" (RNB/Atlas.D20)

These sets of chronicles are also associated with land tenure modifications due to industries strategies to expand sugarcane crops to attend energy demands. In general, smallholders follow the logic that if: "I have little land and no money to invest in it ... I'm actually a wretch ... and if the industry comes and gives me a better condition ... this is good!" (RNB/Atlas.D21). As a result land leasing promoted a significant phenomenon of rural gentrification where "the small crops have disappeared and you can only see pasture, sugar cane, soy ..." (RNB/Atlas.D22).

For some members of Ceres' civil society, the lack of greater reflection, community engagement and voice mask environmental issues that had been neglected by the appropriate authorities. "No one here is being heard ... this wiped out our waters ... rushing rivers, today are like narrow creeks, others simply went dry... it's very sad..." (RNB/Atlas.D23). I hope that the number of plants stops increasing here... monoculture expansion charges a very high price to compensate job offers ... our environment pays a very high price" (RNB/Atlas.D24). 


\section{A. Renovabio's discursive contradictions concerning governance performance}

The first element to be observed when we contrast discourses and practices is connected to the absence of perspectives of decentralized forms of governance. Renovabio concretely did not incorporate any perspective for the federal government to share competences with regional and local governments (Table III.i). The 'new' policy strictly followed Proálcool and $P N P B$ hierarchical structures and remained centralized, without any debates on the creation of new mediation arenas to deliberate over biofuels development.

TABLE III: RENOVABIO’S GOVERNANCE INDEX

\begin{tabular}{|c|c|c|c|c|}
\hline \multirow[b]{2}{*}{$\begin{array}{l}\text { Governance sub-indices } \\
\text { and indicators }\end{array}$} & \multicolumn{4}{|c|}{ Calculation Method } \\
\hline & \begin{tabular}{|c} 
Indices \\
and \\
indicators \\
Weights \\
\end{tabular} & Qualitative & Quantitative & $\begin{array}{c}\text { Quantitative } \\
X \\
\text { Weight }\end{array}$ \\
\hline $\begin{array}{l}\text { 1)Decentralization } \\
\text { i)Local Government } \\
\text { autonomy on energy } \\
\text { regulation } \\
\text { ii)Other prerogatives } \\
\text { delegated from central } \\
\text { government } \\
\text { Sub-total }\end{array}$ & $\begin{array}{l}0,25 \\
0,60 \\
0,40 \\
1,00\end{array}$ & $\begin{array}{c}V U \\
U\end{array}$ & $\begin{array}{l}-2 \\
-1\end{array}$ & $\begin{array}{l}-0,40 \\
-1,20 \\
-0,40 \\
-1,6\end{array}$ \\
\hline $\begin{array}{l}\text { 2)Participation } \\
\text { i)Existence of } \\
\text { Committees, councils or } \\
\text { public audiences } \\
\text { ii)Representativeness of } \\
\text { civil organizations } \\
\text { iii)Cooperation and } \\
\text { partnerships } \\
\text { Sub-total }\end{array}$ & $\begin{array}{l}0,50 \\
0,25 \\
0,25 \\
1,00\end{array}$ & $\begin{array}{c}V U \\
V U \\
U\end{array}$ & $\begin{array}{l}-2 \\
-2 \\
-1\end{array}$ & $\begin{array}{l}-0,43 \\
-1,00 \\
-0,50 \\
-0,25 \\
-1,75\end{array}$ \\
\hline $\begin{array}{l}\text { 3)Transparency \& } \\
\text { Accountability }\end{array}$ & & & & \\
\hline $\begin{array}{l}\text { i) Public access to } \\
\text { technical and political } \\
\text { implementation } \\
\text { ii)Land Planning and } \\
\text { raw material ecological } \\
\text { zoning } \\
\text { iii)Penalties and } \\
\text { responsibility } \\
\text { Sub-total }\end{array}$ & $\begin{array}{l}0,25 \\
0,40 \\
0,30 \\
0,30 \\
1,00\end{array}$ & $\begin{array}{l}F \\
U \\
F\end{array}$ & $\begin{array}{c}1 \\
-1 \\
1\end{array}$ & $\begin{array}{r}0,10 \\
0,40 \\
-0,30 \\
0,30 \\
0,40\end{array}$ \\
\hline 4) Equity & 0,25 & & & $-0,40$ \\
\hline $\begin{array}{l}\text { i) Renovabio CBio's } \\
\text { rights distribution debate } \\
\text { ii) Political influence on } \\
\text { policy formation }\end{array}$ & $\begin{array}{l}0,60 \\
0,40\end{array}$ & $\begin{array}{c}V U \\
U\end{array}$ & $\begin{array}{l}-2 \\
-1 \\
-\end{array}$ & $\begin{array}{l}-1,20 \\
-0,40\end{array}$ \\
\hline Sub-total & 1,00 & & & $-1,60$ \\
\hline Total & & & & $-1,13$ \\
\hline
\end{tabular}

The policy debate did not ventured any discussions about further autonomy and other prerogatives related to environmental, social, and economic matters at subnational levels (Table III.1). That means that rural communities, urban and peri-urban areas settled in energy landscapes, as it is the case of Ceres, remained exclusively under top-down ordinances determined exclusively by central stakeholders.

Participation was another governance aspect that was neglected during the legislative process and, consequently, in the policy design. No public hearings, audiences or open commissions were established to publicize and foster the debates around the bill proposal (Table III.2). On the contrary, the legislative process was accelerated through a rite of urgency, an instrument provided for the 'Rule of Procedures', when at least 257 parliamentarians or their respective party leaders ratify their need.

In this context, apart from public participation the parliamentarian debate and the polling took place simultaneously at National Congress. The proposal was approved by the Lower House in 14 days (14th Nov.2017 28th Nov.2017), and by the Upper House in12 days (30th Nov.2017 - 12th Dec. 2017). No substantial modifications were made from the initial rapporteur considerations in the Chamber of Deputies and in the Senate's Economic Affairs Commission, which was in charge of the final deliberation on the Renovabio's proposal.

The speed of the legislative process along with the absence of participation instruments significantly reduced public access to the policy-making process. Moreover, debate within Congress was severely curtailed, for the bill proposal was never submitted to the Congress Environment Committee or any other consolidated legislative committees.

Besides narratives that: "Renovabio's went from being a government program to become a society program" (RNB/Atlas.D25) the representativeness of civil associations, social movements, and environment groups were null (Table III.ii). According to one of the community leaders we heard, it means that ordinary people rarely have voice on biofuel expansion and "If we talk, they convince you in another way ... when you realize is surrounded by acres of sugarcane" (RNB/Atlas.D26).

Cooperation and partnerships were also another unfavourable aspect under the perspectives on CBio's certifications for both ethanol and biodiesel markets (Table 2.iii). According to a specialized biofuel analysis, the policy "is already inducing a portion of the ethanol market to work to limit biodiesel additions to growth and sell more credits" (RNB/Atlas.D27) showing a fierce competition scenario that presents more concerning to access and guarantee the majority of the financial flows than to promote partnerships to reduce carbon emissions.

Renovabio's expedite approval in the National Congress similarly compromised wider access to technical and administrative data and reduced further considerations about social and environmental outcomes and accountability mechanisms (Table III.i). The 'sustainable production 'or 'environment efficiency' discourses make this contradiction evident when we take into account the gaps between in Brazilian Forest Code).

Although with isolated critics that pointed that the 2012 changes in the Brazilian Forest Code was responsible "for granting amnesty to $94 \%$ of illegally cleared properties in the country, and to facilitate further los of forests by neglecting the need of ecological zoning for other biomes beyond the Amazon" (RNB/Atlas.D28) the prevailing rationality was not to impose further restrictions to limit biofuels production or to establish new limitations to raw materials as soybean and sugarcane over sensitive biomes since: "we cannot, through 
the project that seeks energy efficiency, modify the Brazilian Forest Code" (RNB/Atlas.D29).

Congress members decided that Renovabio was not competent to overlap or redefine the set of forest regulations neither wanted to limit the supply of raw material by means of restrictive ecological zoning. According to an interviewee that works for an environmental NGO, the lack of these precautions makes "unclear whether the government will not give even more incentives to those who plant in sensitive areas such as the Amazon and the Cerrado" (RNB/Atlas.D30), reflecting a common concern among several social actors referring the possible negative environmental outcomes. In other words, instead of perfecting the code, Renovabio took advantage of the brakes and legal loopholes in the environmental legislation.

Meanwhile, the spreading of raw material crops over the Brazilian savannah (Cerrado) makes a "lot of people claim that production is good, but real purposes seek only to give themselves credibility, (RNB/Atlas.D31) as described through a Quilombola leader (Afro-Brazilian rural communities) squeezed between a large sugarcane plantation and the Almas river, in an area controlled by a French energy group. He adds that "today the workforce is almost 80 percent outsourced ... they wanted to earn more than to value its employees" (RNB/Atlas.D32).

"There are a number of aspects that really do not give us any certainty that this goal [to reduce GHG emissions] will be achieved without creating profound socio-environmental problems (RNB/Atlas.D33) as reveled for one energy specialist and expressed as a doubt about one of the main ANP directors, who claims that "there is no definite position of the agency on Renovabio's environmental rules" (RNB/Atlas.D34), reveling an important incongruence in an authoritative narrative employed to legitimize the 'environmental efficiency' and '(bio)energy efficiency'.

This leads to another important point concerning the correlation of efficiency, energy, and market demand that is central to the rationalities and narratives around Renovabio's outcomes. A pattern that carries caveats as highlighted by a local energy engineer, according to whom "even improving energy production efficiency, it may cause further changes in land use for raw materials in the future" (RNB/Atlas.D35) referring to a Jevons paradox phenomena when technological advances to improve efficiency usually implies further consumption of natural resources due to an overall increasing demand.

These aspects reinforce the concerns about the forecast penalties \& responsibilities under Renovabio's rules (Table III.iii) questioning the 'efficiency' of auditing firms to assure mechanism to identify and penalize nonconformities. The methodology used in RenovaCalct, the life cycle assessment tool - to estimate emissions from land use change is controversial, particularly indirect land change. The main challenge is to efficiently track back the use of 'eligible raw materials' in order to sort those who are producing accordingly to Forest Code from others that may be using cultivating in illegally cleared areas.

Another contradiction is the absent debate on distributive rights and compensations vis a vis the free market discourse
(Table III.4.i). According to a secretary from the Ministry of Energy " a lot of people think Renovabio is an indirect subsidy for biofuels. But it is not. It is much more than that" (RNB/Atlas.36). However, according to a specialized biofuel magazine "the very first ethanol plant to reach necessary requirements must receive around US 3.8 million issuing CBio's just in 2020 across the mandatory stock market" (RNB/Atlas.36) giving an estimate of the large financial resources bioenergy plants would expect to raise under the new biofuels policy.

This refers to one of the most questionable elements on policy formation (Table III.4.ii). Renovabio did not consider any forecast discussions to designate some stock market flows as well as part of energy revenues, fees and taxes to be invested in social programs in the communities directly impacted by the expansion of monocultures. Accordingly, no provision was made to support programs to recover watershed basins or degraded areas. This absence seems to be implied to the lack of social actors' voice and representativeness comparing to the influence of large interest groups campaigns and lobby strategies that resulted on the prevailing assumptions that no further environmental safeguards would be necessary.

Considering the sub-indices and indicators we selected as drivers to evaluate Renovabio's governance on policy formation the results pointed out to a very unfavourable frame. Within the range between -2.00 and 2.00 adopted in this qualitative / quantitative assessment the National Biofuels Policy reached only -1.13 reflecting a poor performance, which debunks the image of an innovative policy designed to be mark in the biofuels regulatory framework.

\section{DISCUSSION}

As the study initially assumed results pointed out to the dominance of a clear ecological modernization discourse in the Renovabio's policy formation and implementation. Narratives, statements, speeches, campaigns, and ordinances texts exalted the sustainability of biofuels. Key elements in those narratives included energy efficiency; environment efficiency; technology; innovation; energy security; and development.

The broad sense around the need to increase 'cleaner' energy sources exploring biofuels economical and technical attributes played an important rationality that dominates visions, beliefs, and political parties' guidance through a fast political agreement on policy formation. Additionally, the commitments of the Brazilian government to the Paris Agreement opened an unusual opportunity window to reach consensus on the bill approval.

The Parliamentarian Fronts (Bancadas) that usually oppose each other on several issues, bureaucrats, and lobbyists followed the same rationale: "Who is against producing more biodiesel and decreasing the use of oil, gasoline, diesel? Who is against investing more in renewable energy and less in non-renewable energy?"(RNB/Atlas.D38).

Renovabio's policy formation as highlighted by De Man \& German [8] followed a rationality consensus to legitimize 
and certify biofuels sustainability from a market-based governance point of view. The policy endorsed private sector standards and certifications schemes as sufficient tools to reach good public regulation and efficiency on energy production and environment conservation.

The narratives and speeches from local actors however do not endorse the same rationalities neither reflects the forms and perspectives that sustainability was deployed by the policy makers. On the contrary, they reflect a very realistic view of social, environmental and economic impacts linked to the expansion of bioenergy and biofuel production in their region. While on the one hand they highlight opportunities for material prosperity, on the other hand they reveal negative perspectives on social and environmental issues.

This market-based governance implemented for Renovabio's guidelines this sense seems to opened a very questionable structure and future scenario since it did not incorporate further debates about possible distribution of rights from the massive financial flows CBio's will generated to create environmental safeguards and compensations to recover degraded areas or to recuperated watershed basins as well as to mitigate several social impacts related to biofuels raw material expansion.

As a matter of fact this 'innovative' Biofuels policy reproduced old expedients from traditional bioenergy policies (Proálcool and PNPB) while it did not allow balanced equity amongst social actors and stakeholders involved. The policy formation itself was controlled by hegemonic sectors and their narratives excluding society participation, voice and representativeness. Additionally, policy guidelines reproduced traditional top-down structures remaining controlled for official agents, federal institutions and large companies and without supplementary delegations to states, local government and communities.

Using an ecological modernization rationality Renovabio's reproduced power relations asymmetries using a set of repertoires of concepts, rationalities and assumptions to establish a discursive coalition that concretely did not match to a perspective of an innovative and sustainable biofuel policy. Renovabio's purposes and guidelines resulted in rules, regulations and procedures mainly constructed from and to respond the most resourceful players, interest groups and lobbies settled and represented at the Brazilian Parliament.

\section{CONCLUSION}

The work hopes to shed some lights to the necessary debate on the power relations, governance and sustainability in (bio)energy policies. The study intended this way to call attention to the use of sustainability perspective during the political formation and thru the consolidation of linked governance systems. Interconnections and processes that may promote conceptual distortions that needs to be avoided in order to fall on the reproduction of traditional unsustainable rationalities and practices. In other words, the use of standards and certifications exclusively established on technological and economic nature that lead to a weak sustainability understanding and fails to incorporate essential parameters.
Future analyzes will reveal Renovabio success to achieve expected results without increasing negative socioenvironmental impacts from the intensification use of first generation biofuels. Concretely, despite the 'new clothes' it seems that political and productive arrangements go forward to reproduce traditional expedients of previous Brazilian biofuel policies that dimed society participation and representativeness over biofuel development.

\section{REFERENCES}

[1] Escobar, J.C., et al., Biofuels: environment, technology and food security. Renewable and sustainable energy reviews, 13(6-7): pp. 1275-1287, 2009.

[2] Dauvergne, P. and K.J. Neville, Forests, food, and fuel in the tropics: the uneven social and ecological consequences of the emerging political economy of biofuels. The Journal of peasant studies, 37(4) pp. 631-660, 2010.

[3] Hunsberger, C., et al., Livelihood impacts of biofuel crop production: Implications for governance. Geoforum, 54, pp. 248-260, 2014.

[4] Bailis, R., et al., Biofuel sustainability in Latin America and the Caribbean-a review of recent experiences and future prospects. Biofuels,. 5(5): pp. 469-485, 2014.

[5] Labruto, N., Experimental biofuel governance: Historicizing social certification in Brazilian ethanol production. Geoforum, 54: pp. 272 $281,2014$.

[6] Janssen, R. and D.D. Rutz, Sustainability of biofuels in Latin America: Risks and opportunities. Energy Policy, 39(10): pp. $5717-$ 5725, 2011.

[7] Schaffel, S.B. and E.L. La Rovere, The quest for eco-social efficiency in biofuels production in Brazil. Journal of Cleaner Production, 18(16-17): pp. 1663-1670, 2010.

[8] De Man, R. and L. German, Certifying the sustainability of biofuels. Promise and reality. Energy Policy, 109: pp. 871-883, 2017.

[9] Lima, A. and F. Toni, Energy Landscapes and Environmentality: Boundaries between Discourses and Practices in Energy Governance. Int. J. Environ. Sci. 8(9): pp. 673-677, Dec, 2017.

[10] Lima, M.G.B., Biofuel governance and international legal principles is it equitable and sustainable. Melb. J. Int'l L. 10: pp. 470-480, 2009.

[11] Bailis, R. and J. Baka, Constructing sustainable biofuels: governance of the emerging biofuel economy. Annals of the Association of American Geographers,. 101(4): pp. 827-838, 2011.

[12] Hajer, M.A., The politics of environmental discourse: ecological modernization and the policy process. 1995: Clarendon Press Oxford.

[13] Dryzek, J.S., The politics of the earth: Environmental discourses. Oxford university press, 2013.

[14] Feindt, P.H. and A. Oels, Does discourse matter? Discourse analysis in environmental policy making. Journal of Environmental Policy \& Planning, 7(3): pp. 161-173, 2005.

[15] Hajer, M. and W. Versteeg, A decade of discourse analysis of environmental politics: Achievements, challenges, perspectives. Journal of environmental policy \& planning, 7(3): pp. 175-184, 2005.

[16] Luke, T.W., On environmentality: Geo-power and eco-knowledge in the discourses of contemporary environmentalism. Cultural Critique, (31): pp. 57-81, 1995.

[17] Faber, D., Capitalizing on environmental injustice: the polluterindustrial complex in the age of globalization. Rowman \& Littlefield Publishers, 2008.

[18] Jacques, P.J., R.E. Dunlap, and M. Freeman, The organisation of denial: Conservative think tanks and environmental scepticism. Environmental politics, 17(3), pp. 349-385, 2008.

[19] Matz, J. and D. Renfrew, Selling "fracking": Energy in depth and the Marcellus Shale. Environmental Communication, 9(3): pp. 288-306, 2015.

[20] Wolff, B.G., Environmental studies and utilitarian ethics. Bioscene: Journal of College Biology Teaching, 35(2): pp. 42-46, 2009.

[21] Braun, B., Producing vertical territory: geology and governmentality in late Victorian Canada. Ecumene,. 7(1): pp. 7-46, 2000.

[22] Alier, J.M., De la economía ecológica al ecologismo popular. Vol. 60. Icaria Editorial,1994.

[23] Forbes, L.C. and J.M. Jermier, The new corporate environmentalism and the ecology of commerce. Organization \& environment, 23(4) pp. 465-481, 2010 
[24] Brulle, R.J., From environmental campaigns to advancing the public dialog: Environmental communication for civic engagement. Environmental Communication,. 4(1): pp. 82-98, 2010.

[25] Consentino, L., Interesses organizados na cena internacional: o lobby do etanol. Ph.D Dissertation. Faculdade de Filosofia, Letras e Ciências Humanas, Universidade de São Paulo, 2011.

[26] Bruno, R., Bancada ruralista, conservadorismo e representação de interesses no Brasil contemporâneo. Questões agrárias, agrícolas e rurais. Conjunturas e políticas públicas, E-papers, Rio de Janeiro, pp. 155-168, 2017.

[27] Ribeiro, F., Álcool e açúcar: uma via de mão dupla. Álcoo combustível-série indústria em perspectiva. Brasília: Instituto Evaldo Lodi, pp. 48-57, 2008.

[28] De Moraes, M.A.F.D. and D. Zilberman, Production of Ethanol from Sugarcane in Brazil: from state intervention to a free market. Vol. 43. Springer Science \& Business Media, 2014.

[29] Schneider, B.R., The developmental state in Brazil: comparative and historical perspectives. Brazilian Journal of Political Economy, 35(1): pp. 114-132, 2015.

[30] Sandalow, D., Ethanol: lessons from Brazil. A high growth strategy for ethanol, pp. 67-74, 2006.

[31] Goldemberg, J., S.T. Coelho, and P. Guardabassi, The sustainability of ethanol production from sugarcane. Energy policy, 36(6): pp. 2086-2097, 2008.

[32] Granco, G., et al., Exploring the policy and social factors fueling the expansion and shift of sugarcane production in the Brazilian Cerrado. GeoJournal, 82(1): pp. 63-80, 2017.

[33] Castillo, R., Dinâmicas recentes do setor sucroenergético no Brasil competitividade regional para o bioma Cerrado. GEOgraphia,. 17(35): p. 95-119, 2015.

[34] Stattman, S.L., O. Hospes, and A.P. Mol, Governing biofuels in Brazil: A comparison of ethanol and biodiesel policies. Energy Policy,. 61: pp. 22-30, 2013.

[35] Becker, B.K., Recuperação de áreas desflorestadas da Amazônia: será pertinente o cultivo da palma de óleo (Dendê)? Confins. Revue franco-brésilienne de géographie/Revista franco-brasilera de geografia, vol.10, 2010.

[36] Hall, J., et al., Brazilian biofuels and social exclusion: established and concentrated ethanol versus emerging and dispersed biodiesel. Journal of Cleaner Production, 17: pp. S77-S85,. 2009.

[37] De Lima, A. and F. Toni, The Energy Leviathan: or how US Shale and Brazil Biodiesel Governance Systems Fail to Promote Decentralization, Accountability, Equity, and Society Participation. European Journal of Sustainable Development,. 7(3): pp. 1-10, 2018.

[38] Amaral, A., Regulação do RenovaBio. RENOVABIO: Próximos Passos. Rio de Janeiro: FGV Energia, 2018.

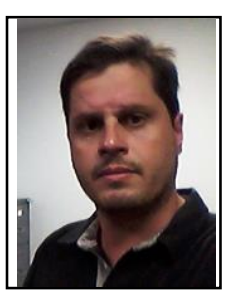

Arnoldo Lima was born in Santa Maria, Brazil on August 28, 1973. He graduates in geography (2005). and received his $\mathrm{Ph} . \mathrm{D}$. on policy and sustainability management in 2016 from the Center for Sustainable Development (CDS) at University of Brasília (UnB).

His main research field is resource governance and environmentality. He has being studying socioenvironmental impacts linked to energy and bioenergy production since 2009. In 2014 he was invited to the Human-Environment Research Group at Texas A\&M University/Dpt. Of Geography when he worked as a collaborative researcher in Eagle Ford Shale energy landscape. Currently he is Ad-Hoc Advisor for Federal District Research Foundation (FAPDF) and Postdoctoral Associated Researcher at CDS/UnB. 